\title{
Can clinical and physical-functional factors predict falls in cognitively impaired older adults?
}

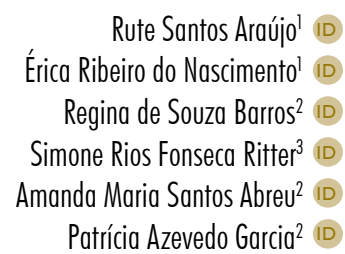

Abstract

Objective: to investigate the frequency of falls and clinical and physical-functional factors associated with falls, and the accuracy of such factors to identify the risk of falling in cognitively impaired older adults. Method: a cross-sectional study with cognitively impaired older adults was carried out using the Mini-Mental State Examination. The dependent variable was a history of falls in the previous six months. The independent variables were self-reported mental confusion, hearing and visual impairment, physical fatigue, muscle weakness, dizziness, body imbalance, insecurity when walking, diagnosed depression, hospitalizations, continuous use medications (form from study used), muscle mass (calf circumference) and handgrip strength (dynamometry), functional capacity (Pfeffer) and mobility (SAM-Br). Descriptive statistics were applied. The groups were compared using the Mann Whitney $\mathrm{U}$ test, the risk factors were identified by univariate and multivariate logistic regression, and the area under the ROC curve (AUC) was calculated for the associated factors. Results: 216 cognitively impaired older adults were included in the analysis, $41.7 \%$ of whom were fallers. Multivariate regression analyzes indicated that complaints of visual impairment $(\mathrm{OR}=2.8 ; p=0.015)$ and body imbalance $(\mathrm{OR}=2.7 ; p=0.004)$, and greater medication use $(\mathrm{OR}=1.1 ; p=0.038)$ were associated with a history of falls. The AUC found poor accuracy for quantity of medications as a screening tool for fallers (AUC $=0.6[0.5 ; 0.7] ; p=0.028)$. Conclusion: cognitively impaired older adults had a high frequency of falls. Complaints of visual impairment, body imbalance and polypharmacy were predictors of falls. The early assessment of these factors can contribute to the identification of cognitively-impaired older adults at risk of falling in clinical practice and research.

\footnotetext{
Universidade de Brasília, Faculdade de Ceilândia, Curso de Fisioterapia. Brasília, DF, Brasil.

2 Universidade de Brasília, Faculdade de Ceilândia, Programa de Pós Graduação em Ciências da Reabilitação. Brasília, DF, Brasil.

3 Secretaria de Saúde do Distrito Federal, Geriatria, Policlínica 1, Região Oeste. Brasília, DF, Brasil.
}

Keywords: Health of the Elderly. Cognition Disorders. Accidental Falls. Risk Factors. Mass Screening.

The authors declare there are no conflicts of interest in relation to the present study.

No funding was received in relation to the present study.

Correspondence

Patrícia Azevedo Garcia 


\section{INTRODUCTION}

Cognitive impairment and dementia are important clinical syndromes and a common health concern in older adults ${ }^{1}$. Mild Cognitive Impairment (MCI) is considered an intermediate state between the normal cognitive changes of aging and the early clinical characteristics of dementia, particularly Alzheimer's disease $^{2}$. Dementia, meanwhile, relates to progressive neurodegenerative processes that affect various areas of cognition ${ }^{1}$. It is estimated that MCI is present in $16 \%$ of the population aged over 70 years ${ }^{3}$. The consequent deficits in memory, temporal orientation, language, problem solving, attention, motor initiation and executive functions related to planning and working memory can result in impairments in the functional capacity of these older adults and increase the risk of falls ${ }^{1,3}$.

Falls represent a severe problem for cognitively impaired older adults ${ }^{4}$. Approximately $60 \%$ of such adults fall each year ${ }^{5}$. This rate is approximately double that of non-cognitively impaired older adults $^{1}$. Falls negatively affect function, can cause bone fractures, chronic pain, depression and fear of falling, reduce quality of life and are associated with frailty and death ${ }^{3,6}$. In addition, a long-lived cognitively impaired older adult who is a victim of falls is at greater risk of serious injury, resulting in excessive health costs ${ }^{3,7}$.

Older patients with MCI have multiple chronic conditions, reduced mobility, deficiencies in muscle strength, reaction time, balance and sensorimotor, and a greater fear of falling, explaining their greater predisposition to falls ${ }^{8,9}$. A history of falls ${ }^{6,10}$, poor performance in balance and gait tests and increased postural sway have been shown to be associated with the risk of falling ${ }^{4,6,10-12}$. Neuro-cardiovascular problems ${ }^{11}$, declining verbal fluency ${ }^{10}$, attention deficit, spatial disorientation, use of psychotropic drugs $^{13}$ and polypharmacy ${ }^{8,10}$ are equally related to falls. In the same way, depression ${ }^{6,8}$, high levels of anxiety ${ }^{4}$ combined with impulsivity and agitation ${ }^{4}$ increase the chance of falling in older adults with dementia.

These clinical and physical-functional characteristics have already been shown to be related to the increased likelihood of falls in older adults with cognitive deficits and dementia. However, most studies have investigated these risk factors using specialized instruments and with greater evaluation complexity $y^{4,8-10,12}$.

The hypothesis of the present study is that common complaints related to the clinical and physical-functional components reported by older adults with cognitive deficits and/or by their caregivers are also associated with the occurrence of falls and enable the early identification of older adults at greater risk in a comprehensive manner by the entire health team. In this context, the objectives of the present study were to investigate the frequency of falls, the clinical and physical-functional factors associated with the same and the accuracy of these factors to identify the risk of falling in cognitively impaired older adults.

\section{METHOD}

An observational, cross-sectional and analytical study was undertaken. The sample, selected for convenience, was recruited from January 2018 to January 2019 at an older adults care service in a secondary care unit of the State Department of Health of the Distrito Federal (the Federal District), Brazil. This health unit serves, for the most part, older adults from the western health region of the Distrito Federal, in which approximately 90,000 older adults live, according to the District Household Sample Survey, 2015. This unit provides care for older adults aged over 60 years of age, referred from primary care units, with morbidities that are difficult to control, multi-comorbidities, polypharmacy or clinical conditions (such as neurocognitive diseases) that require specialized evaluation by the geriatric team. All referred older adults are evaluated during intake and, based on this first multidimensional evaluation, are admitted for follow-up at the geriatric service or counter-referred to primary care with appropriate instructions.

The present study included older community residents of both sexes, aged 60 years or older, who presented cognitive disorders according to the MiniMental State Examination (MMSE). To identify cognitive impairment, the following cutoff points 
were adopted: 28 for individuals with more than 7 years of schooling, 24 for those with 4-7 years of schooling, 23 for those with 1-3 years of schooling and 19 for illiterates ${ }^{14}$. Older adults who presented records with ineligible or incomplete data from the cognitive assessment and/or the occurrence of falls were excluded.

The sample calculation was performed in the GPower version 3.1 program with the first 20 fallers and 20 non-fallers included in the study, based on the effect size of the intergroup comparison for the variables: amount of continuous use medications $(\mathrm{d}=0.70)$, muscle mass $(\mathrm{d}=0.78)$, functional capacity $(d=0.50)$ and mobility $(d=0.55)$. In order to guarantee a power of $90 \%$ and an alpha error of $5 \%$ in these comparisons, a minimum sample of 172 participants was calculated (86 fallers and 86 non-fallers older adults).

Falls were the dependent variable of the study and were defined as the occurrence of an unintended event that results in the individual's position changing to a lower level, in relation to their initial position ${ }^{15}$. This variable was identified through self-reporting, with the older adult and/or their caregiver asked: Did the older adult suffer a fall in the last six months? Those who responded positively were asked about the number of falls during this period. According to the number of falls reported, older adults were grouped into non-fallers (0 falls) or fallers (1 or more falls) individuals.

The independent variables were the clinical and physical-functional characteristics of older adults. Data were collected using an initial form, developed by the researchers, and specific instruments of rapid, low complexity application, validated for individuals with cognitive impairment, used in the intake service. The questions were directed at the older adult and/ or their caregiver.

The clinical data, investigated by means of self-reporting (presence or absence) were: mental confusion, hearing and visual impairment, physical tiredness, diagnosis of depression, history of hospitalizations and number of continuous use medications. Mental confusion was characterized as a change in the level of consciousness with a reduced attention span accompanied by a change in cognition or disturbance of perception that developed over a short period of time (hours or days) and which tended to fluctuate throughout the day ${ }^{16}$. To identify the presence of hearing impairment, personal perceptions were identified through the question Do you feel you have hearing loss? Visual impairment was identified by asking the individuals about their ability to see clearly during routine activities, under various levels of light, considering visual acuity, contrast sensitivity and depth perception. ${ }^{17}$ Physical fatigue was characterized by the sensation perceived by the older adult or by their caregiver as an unpleasant subjective symptom that varies from tiredness to exhaustion, and which interferes with the normal functioning capacity and quality of life of these individuals ${ }^{18}$. The presence of depression was identified by means of a previous medical diagnosis reported by the older adult or their caregiver and the history of hospitalizations through the report of hospitalization or admission to an emergency care unit for at least 24 hours in the previous six months. They were asked about the number of continuous use medication, and polypharmacy was defined as the regular use of five or more medications associated with the reported diseases (excluding dietary supplements) ${ }^{19}$.

The physical and functional data investigated through self-reporting (presence or absence) were complaints of muscle weakness, dizziness, body imbalance and insecurity when walking. Muscle mass, muscle strength, mobility and functional capacity were also measured. The complaint of muscle weakness was identified through the question Do you have difficulty getting up from a chair ${ }^{20}$. Dizziness was defined as the feeling of instability or imbalance, which can generate the fear of falling ${ }^{21}$. Body imbalance represented the loss of the ability to control the intentional movements of the body mass center on the support base during the performance of activities that involved the transfer of weight ${ }^{22}$. Insecurity when walking was determined by excessive worry or anxiety about falling that limits the performance of activities of daily living ${ }^{23}$.

Muscle mass was inferred by measuring calf circumference (CC), in centimeters, using a tape measure. This measurement was performed on the dominant limb with the older adults sitting, with their knee flexed and their feet supported, 
forming a right angle in the knee and ankle joints. The measuring tape was positioned horizontally around the maximum calf circumference ${ }^{24}$.

Muscle strength was measured using the isometric handgrip strength (HGS) in Kgf using a Saehan ${ }^{\circledR}$ manual hydraulic dynamometer. This measure has excellent reliability in older adults with questionable, mild and moderate dementia, enabling its use in research and clinical practice. ${ }^{25}$. For the assessment of HGS, the older adults were seated, with their feet touching the ground and the dominant upper limb in adduction, the elbow joint flexed at $90^{\circ}$ and the forearm in the neutral position ${ }^{26}$. Three attempts were made, with a one-minute interval between each, and the average of these measures was used for analysis.

The mobility of the older adults was assessed using the Brazilian version of the Southampton Assessment of Mobility (SAM-BR). This instrument assesses the performance of older adults with cognitive impairment in 18 items, based on the assessment of five tasks, for which they receive a score of 1 (if performed) or 0 (if not performed) in each item, with a total score from 0 to 18 points. It is a simple control instrument, with easy and effective clinical applicability, and which has demonstrated "almost perfect" intra-examiner and inter-examiner agreement for mild and moderate dementia (Kappa from 0.79 to 0.89$)^{27}$.

The functional capacity of the older adults was assessed using the Pfeffer ${ }^{28}$ questionnaire, which was applied to the caregiver to assess the degree of independence of older adults for the performance of ten tasks. The final score was obtained by adding the scores of the items $(0-30)$.

To characterize the participants, age, sex, years of schooling, level of physical activity, nutritional status and reports of previous diagnosis of dementia were identified. To determine the level of physical activity of the older adults, they were asked how many minutes per week they practiced physical exercise of moderate to vigorous intensity, and were classified into active ( $\geq 150$ minutes of moderate activity per week or $\geq 75$ minutes of vigorous activity) or sedentary ${ }^{29}$. Body Mass Index [BMI= body mass $(\mathrm{kg}) /$ height $\left.^{2}\left(\mathrm{~m}^{2}\right)\right]$ was calculated, which allowed the nutritional status of the older adults to be classified as underweight $\left(\mathrm{BMI}<22 \mathrm{~kg} / \mathrm{m}^{2}\right)$, normal weight (BMI $\left.22-27 \mathrm{~kg} / \mathrm{m}^{2}\right)$ or overweight $\left(\mathrm{BMI}>27 \mathrm{Kg} / \mathrm{m}^{2}\right)^{30}$.

The collection of sociodemographic, clinical, anthropometric and physical-functional data was performed in a single day, by seven trained examiners from the nursing and physiotherapy team, and lasted approximately one hour.

Continuous data were expressed as mean and standard deviation and categorical data as percentage and absolute frequency. The non-normal distribution of continuous data was observed using the Kolmogorov-Smirnov test. The frequency of previous falls was calculated using the number of cases with reports of previous falls and the total number of older adults studied. Differences in continuous data between non-fallers and fallers subgroups were analyzed using the U Mann Whitney test and categorical data using the Chi-square test. Univariate logistic regression analysis was used to determine the association between each independent variable and the dependent variable. Odds Ratios (OR) were calculated for each explanatory variable with 95\% confidence intervals. Subsequently, variables with an association with a $p$-value less than 0.05 in univariate regression analysis were included in the multivariate logistic regression analysis in order to investigate the independent effect, when taken together, of these variables to predict falls in older adults with cognitive deficits. The selection of the best model was carried out using the variable reduction procedure based on the forward stepwise method. In order to analyze the accuracy of the factors that remained associated with falls in multivariate regression analysis, Sensitivity (S), Specificity (SP), Positive Predictive Value (PPV) and Negative Predictive Value (NPV) were calculated. The ROC curve was constructed and the area under the curve (AUC) (with 95\% confidence interval) was calculated for the continuous variables. AUC values between 0.51 and 0.69 represented weak discriminative capacity and AUC values equal to or greater than 0.70 determined satisfactory discriminative capacity. A significance level of $5 \%$ was considered.

The study was approved by the Ethics and Research Committee of the Ceilândia Faculty of the 
Universidade de Brasília (the University of Brasília) under Opinion No. 2,202,958, on August 5, 2017 in accordance with Resolution No. 466 of 2012 of the National Health Council. Older adults included in the study signed an Informed Consent Term after approval by the Ethics Committee.

\section{RESULTS}

During the study period, 336 older adults admitted to the health unit were evaluated for eligibility, of whom 235 had cognitive impairment. Of older adults with cognitive impairment, 216 with complete medical records were included in the analysis, of whom $90(41.7 \%)$ reported an average of $1.9( \pm 1.6)$ falls in the previous six months (Figure 1).
Most older adults included were female, had a low level of education, were sedentary and overweight (Table 1). There was no significant difference between groups in terms of age, sex, education, cognitive status and previous diagnosis of dementia, nutritional status and level of physical activity, representing homogeneity between the groups for possible confounding variables. The comparison of possible factors associated with falls among older adults with cognitive deficits revealed that those who fell used a greater number of continuous use medications, had a higher frequency of the diagnosis of depression and complaints of visual impairment, body imbalance and insecurity when walking. There was no significant difference for muscle mass and strength, mobility and functional capacity between the two study groups (Table 1).

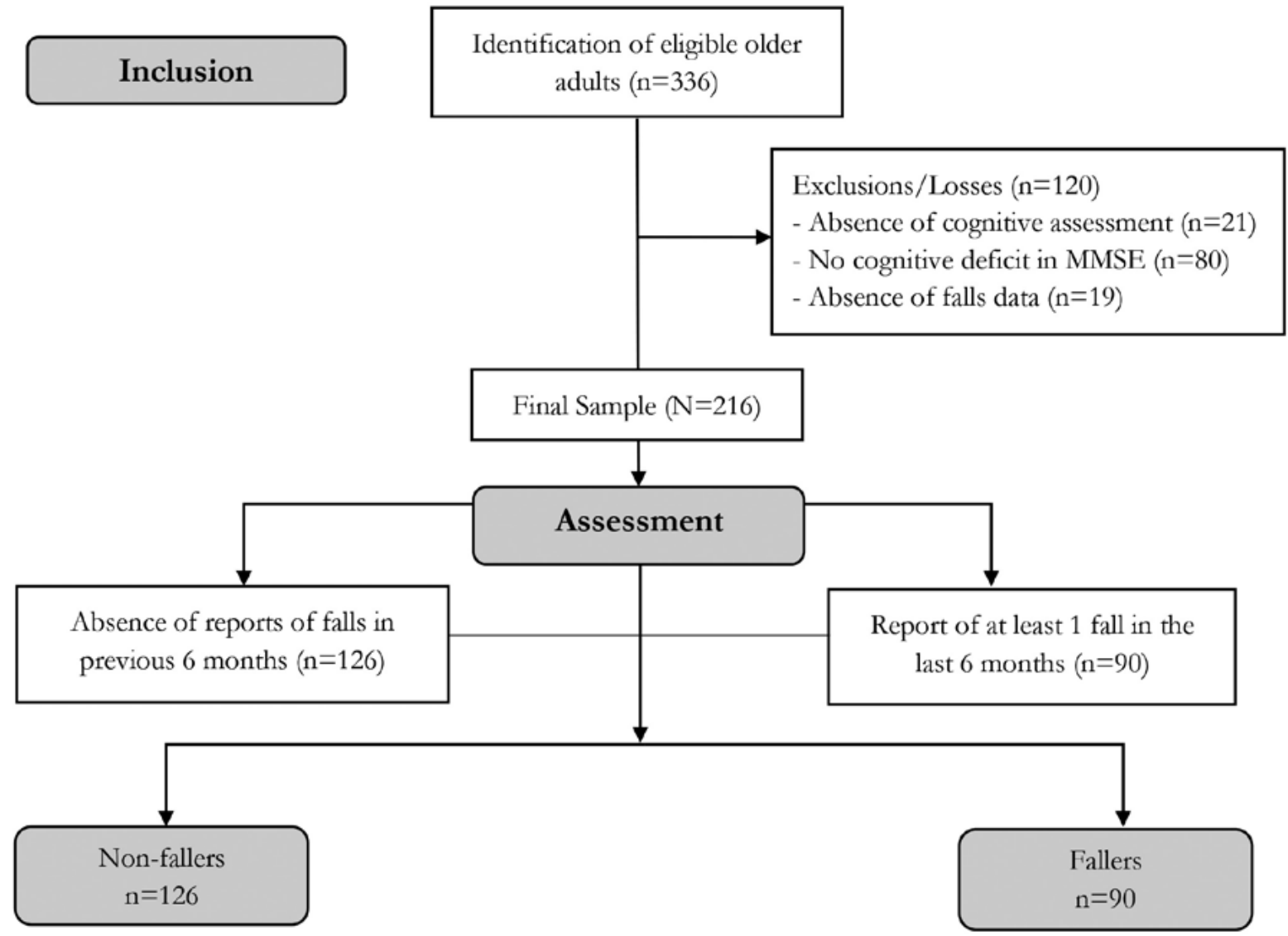

Figure 1. Flowchart of sample selection. Distrito Federal, 2018-2019. 
Table 1. Characterization and comparison of sociodemographic, clinical, anthropometric and physical-functional variables among older fallers and non-fallers with cognitive impairment ( $=216)$. Brasília, Distrito Federal, 2018-2019.

\begin{tabular}{|c|c|c|c|c|}
\hline Variable & $\begin{array}{l}\text { Non-fallers } \\
(n=126)\end{array}$ & Fallers $(n=90)$ & $\begin{array}{l}\text { Mean difference } \\
\text { between groups } \\
{[\text { CI } 95 \%]}\end{array}$ & $p$-value \\
\hline \multicolumn{5}{|c|}{ Sociodemographic, clinical and anthropometric characteristics } \\
\hline Mean age $( \pm s d)^{\dagger}$ & $79.0( \pm 7.2)$ & $77.7( \pm 7.2)$ & $1.2[-0.7 ; 3.2]$ & 0.156 \\
\hline $\begin{array}{l}\text { Sex, } \%(n)^{*} \\
\text { Female } \\
\text { Male }\end{array}$ & $\begin{array}{l}67.5(85) \\
32.5(41)\end{array}$ & $\begin{array}{l}68.9(62) \\
31.1(28)\end{array}$ & - & 0.883 \\
\hline Years of study, mean $( \pm S D)^{\dagger}$ & $2.3( \pm 2.5)$ & $2.8( \pm 3.1)$ & $-0.5[-1.2 ; 0.2]$ & 0.339 \\
\hline Average cognitive state (MMSE) $( \pm \mathrm{SD})^{\dagger}$ & $14.1( \pm 5.8)$ & $15.3( \pm 5.5)$ & $-1.2[-2.7 ; 0.4]$ & 0.250 \\
\hline $\begin{array}{l}\text { Illiterate } \\
1 \text { to } 3 \\
4 \text { to } 7 \\
\geq 8\end{array}$ & $\begin{array}{l}11.1( \pm 4.7) \\
14.6( \pm 5.9) \\
16.8( \pm 5.2) \\
19.7( \pm 5.5)\end{array}$ & $\begin{array}{l}12.3( \pm 3.9) \\
15.6( \pm 5.2) \\
16.1( \pm 4.6) \\
22.5( \pm 5.2)\end{array}$ & & \\
\hline Previous diagnosis of dementia (yes), $\%(\mathrm{n})^{\ddagger}$ & $27.9(34)$ & $24.1(21)$ & & 0.633 \\
\hline BMI, mean $( \pm \mathrm{sd})^{\dagger}$ & $26.5( \pm 4.5)$ & $27.4( \pm 5.6)$ & $-0.9[-2.5 ; 0.7]$ & 0.427 \\
\hline $\begin{array}{l}\text { Nutritional status, \% (n) }{ }^{\ddagger} \\
\text { Low Weight } \\
\text { Normal Weight } \\
\text { Overweight }\end{array}$ & $\begin{array}{l}14.1(13) \\
40.2(37) \\
45.7(42) \\
\end{array}$ & $\begin{array}{l}17.2(11) \\
35.9(23) \\
46.9(30) \\
\end{array}$ & $\begin{array}{l}- \\
- \\
-\end{array}$ & 0.810 \\
\hline Active (yes), $\%(\mathrm{n}){ }^{\ddagger}$ & $8.7(11)$ & $5.6(5)$ & - & 0.440 \\
\hline \multicolumn{5}{|l|}{ Clinical characteristics } \\
\hline Pain (yes), $\%(\mathrm{n})^{\ddagger}$ & $57.1(72)$ & $68.9(62)$ & - & 0.089 \\
\hline Mental confusion (yes), $\%(\mathrm{n})^{\ddagger}$ & $66.1(82)$ & $68.9(62)$ & - & 0.768 \\
\hline Hearing deficit (yes), $\%$ (n) ${ }^{*}$ & $34.1(43)$ & $37.8(34)$ & - & 0.666 \\
\hline Visual impairment (yes), $\%$ (n) $\ddagger *$ & $74.6(94)$ & $87.8(79)$ & - & 0.024 \\
\hline Incontinence (yes), $\%$ (n) ${ }^{\ddagger}$ & $59.5(72)$ & $71.6(63)$ & - & 0.080 \\
\hline Physical tiredness (yes), $\%$ (n) ${ }^{\ddagger}$ & $60.3(76)$ & $67.8(61)$ & - & 0.316 \\
\hline Diagnosis of depression (yes), $\%$ (n) $\ddagger *$ & $33.3(42)$ & $48.3(43)$ & - & 0.034 \\
\hline History of hospitalizations (yes), $\%$ (n) ${ }^{\ddagger}$ & $24.0(29)$ & $24.7(21)$ & - & 0.903 \\
\hline Medications (quantity), mean $( \pm \mathrm{sd}) \dagger *$ & $5.4( \pm 2.8)$ & $6.5( \pm 3.3)$ & $-1.077[-1.9 ;-0.2]$ & 0.027 \\
\hline Polypharmacy (yes), $\%$ (n) ${ }^{\ddagger}$ & $63.1(77)$ & $69.0(60)$ & - & 0.461 \\
\hline \multicolumn{5}{|l|}{ Physical and functional characteristics } \\
\hline Muscle weakness (yes), $\%$ (n) ${ }^{\ddagger}$ & $63.5(80)$ & $76.7(69)$ & - & 0.052 \\
\hline Dizziness (yes), $\%$ (n) ${ }^{\ddagger}$ & $56.3(71)$ & $57.8(52)$ & - & 0.890 \\
\hline Body imbalance (yes), $\%$ (n) ${ }^{\ddagger} *$ & $58.4(73)$ & $80.9(72)$ & - & 0.001 \\
\hline Insecurity when walking (yes), $\%$ (n) $\ddagger *$ & $56.5(70)$ & $70.5(62)$ & - & 0.044 \\
\hline Muscle mass $(\mathrm{cm})$, mean $( \pm \mathrm{sd})^{\dagger}$ & $34.0( \pm 4.8)$ & $34.1( \pm 5.2)$ & $-0.0[-1.5 ; 1.4]$ & 0.794 \\
\hline Muscle strength $(\mathrm{Kgf})$, mean $( \pm \mathrm{sd}){ }^{\dagger}$ & $19.9( \pm 8.1)$ & $17.5( \pm 5.9)$ & $2.5[-0.3 ; 5.3]$ & 0.134 \\
\hline Functional capacity (Pfeffer), mean $( \pm \mathrm{sd})^{\dagger}$ & $18.6( \pm 9.7)$ & $18.0( \pm 9.4)$ & $0.6[-2.3 ; 3.5]$ & 0.627 \\
\hline Mobility (SAM-Br), mean $( \pm \mathrm{sd})^{\dagger}$ & $15.9( \pm 3.7)$ & $16.1( \pm 2.7)$ & $-0.6[-1.7 ; 0.4]$ & 0.250 \\
\hline
\end{tabular}

${ }^{\dagger}$ Mann Whitney U-Test; ${ }^{\ddagger}$ Chi-Squared Test; ${ }^{*} p<0.05$ for comparison between fallers and non-fallers. 
Table 2 shows the results of the assessment of the influence of each independent variable on the occurrence of falls among the older adults studied. Univariate analysis showed that the presence of complaints of visual impairment, muscle weakness, imbalance and insecurity when walking, the report of a previous diagnosis of depression and a greater number of continuous use medications explained falls in older adults with cognitive deficit. However, in multivariate analysis, only the complaint of visual impairment and body imbalance and the use of more medications remained in the final model as predictors of falls. Although these three variables were shown to be predictors, AUC analysis indicated the poor accuracy of polypharmacy (as an independent factor) to predict falls (Table 3).

Table 2. Univariate and multivariate logistic regression analyzes to verify associations between clinical and physical-functional factors and the history of falls in older adults with cognitive impairment $(\mathrm{N}=216)$. Brasília, Distrito Federal, 2018-2019.

\begin{tabular}{lllll}
\hline Variables & \multicolumn{2}{c}{ Univariate Analysis } & \multicolumn{2}{c}{ Multivariate } \\
& OR $[95 \% \mathrm{CI}]$ & $p$-value & OR $[95 \% \mathrm{CI}]$ & -value \\
\hline Clinical & & & & - \\
Pain & $1.7[0.9 ; 2.9]$ & 0.081 & - & - \\
Mental confusion & $1.1[0.6 ; 2.0]$ & 0.671 & - & - \\
Hearing deficiency & $1.2[0.7 ; 2.0]$ & 0.581 & - & $0.015^{*}$ \\
Visual impairment & $2.4[1.1 ; 5.2]$ & $0.019^{* *}$ & $2.8[1.2 ; 6.5]$ & - \\
Incontinence & $1.7[0.9 ; 3.1]$ & 0.072 & - & - \\
Physical tiredness & $1.4[0.8 ; 2.4]$ & 0.262 & - & - \\
Diagnosis of depression & $1.9[1.1 ; 3.3]$ & $0.028^{* *}$ & - & - \\
Hospitalization history (yes) & $1.0[0.5 ; 1.8]$ & 0.903 & - & - \\
Continuous use medications & $1.1[1.0 ; 1.2]$ & $0.014 * *$ & $1.1[1.0 ; 1.2]$ & - \\
\hline Physical-functional & & & - & - \\
Muscle weakness & $1.9[1.0 ; 3.5]$ & $0.040^{* *}$ & - & - \\
Dizziness & $1.1[0.6 ; 1.8]$ & 0.834 & - & $0.004^{*}$ \\
Body imbalance & $3.0[1.6 ; 5.7]$ & $0.001^{* *}$ & $2.7[1.4 ; 5.3]$ & - \\
Insecurity when walking & $1.8[1.0 ; 3.3]$ & $0.039^{* *}$ & - & - \\
Muscle mass (cm) & $1.0[0.9 ; 1.1]$ & 0.936 & - & - \\
Muscle strength (Kgf) & $0.9[0.9 ; 1.0]$ & 0.086 & - & - \\
Functional capacity (Pfeffer) & $1.0[1.0 ; 1.0]$ & 0.672 & - & - \\
Mobility (SAM-Br) & $1.1[0.9 ; 1.2]$ & 0.249 & - & - \\
\hline
\end{tabular}

Multivariate binary logistic regression with forward stepwise method. The data were expressed in OR $[95 \% \mathrm{CI}]$; $* * p<0.05$ in the univariate analysis (variables were included in the multivariate regression analysis); ${ }^{*} p<0.05$ in multivariate analysis.

Table 3. Capacity of risk factors to predict falls in older adults with cognitive impairment ( $\mathrm{N}=216)$. Brasília, Distrito Federal, 2018-2019.

\begin{tabular}{llll}
\hline & Visual impairment & Polypharmacy & Body imbalance \\
\hline Cutoff & Yes & $\geq 5$ medications & Yes \\
\hline Sensitivity (\%) & 87.8 & 68.9 & 80.9 \\
\hline Specificity (\%) & 25.4 & 36.8 & 41.6 \\
\hline PPV (\%) & 45.6 & 43.7 & 49.6 \\
\hline NPV (\%) & 74.4 & 62.5 & 75.4 \\
\hline AUC [95\% CI] & - & $0.6[0.5 ; 0.7]$ & - \\
\hline p-value & - & 0.028 & - \\
\hline
\end{tabular}

PPV = Positive Predictive Value; NPV = Negative Predictive Value; AUC = Area under the curve; ROC. CI = Confidence Interval. 


\section{DISCUSSION}

Older adults with cognitive impairment had a high frequency of falls $(41.7 \%)$. In these adults, complaints of visual impairment and body imbalance reported by older adults and/or their caregivers and the greater number of continuous use medications were associated with reports of falls, and were therefore predictors of falls, but with poor accuracy. The high frequency of falls observed in the present study reiterates that cognitive deficit represents a greater risk of falls among older adults, when compared to the rates of approximately $30 \%$ of fallers among older community members in general ${ }^{19}$. Additionally, it corroborates data from previous studies that observed rates above $60 \%$ for the incidence of falls in 6 to 12 months of follow-up among people with cognitive impairment or dementia, explained by the accumulation of associated comorbidities, reduced mobility and physical capacity, and the need for walking aids among these older adults ${ }^{8,31}$.

In the present study, older fallers had 2.8 times the chance of older non-fallers to complain of visual impairment, with the perception of visual impairment correctly identifying $87.8 \%$ of older fallers, revealing that the assessment of this impairment can make an important contribution in clinical and research settings. The methodology for assessing visual impairment in older adults with cognitive impairment has varied greatly between studies $^{7,32}$. Studies ${ }^{7,32}$ that assessed visual status using the Multidimensional Dementia Assessment Scale and Comprehensive Geriatric Assessment did not indicate visual impairment as a risk factor for falls. However, studies that assessed the visual perception of older adults with dementia using the copy item of the two pentagons that intersect in the MiniMental State Examination and the report of history of cataracts showed that visual impairment behave as a risk factor for falls in these patients ${ }^{1,6}$.

The frequencies of previous diagnosis of depression observed in the present study corroborate rates of approximately $30 \%$ of depression and/or depressive symptoms observed in patients with dementia $^{33}$. Previous studies have shown that depressive symptoms in cognitively impaired older adults are associated with falls ${ }^{1,6,32}$ while in the sample of the present study, older fallers had 1.9 times the chance of non-fallers to report a previous diagnosis of depression. Despite these findings, this factor was not maintained as a predictor of falls in the multivariate analysis of the present study. It is possible that the use of antidepressant drugs, which was not investigated in the present study, is a better independent predictor of falls than depressive symptoms, as observed by Whitney et al. ${ }^{34}$.

Older adults who fell used on average one more continuous use medication than those who did not fall, with polypharmacy correctly identifying $68.9 \%$ of older adults who fell in the present study. The use of multiple medications has been consistently associated with a history of falls in older adults with and without cognitive impairment and/or dementia ${ }^{10}$. Previous studies have shown that drugs that act on the central nervous system, such as antipsychotics, anxiolytics, benzodiazepines, hypnotics, sedatives and antidepressants, increase the risk of falling in cognitively impaired older adults ${ }^{1,6,34}$. However, regardless of the class of drug, it is reiterated that polypharmacy requires special attention in screening, as it seems to increase the likelihood of falling among cognitively impaired older adults , $32,34^{\text {. }}$

In the present study, muscle weakness was a highly frequent complaint in older fallers and non-fallers, accompanied by a high rate of physical inactivity and similar indicators of muscle mass and HGS in both groups of older adults. In univariate analysis, older adults who fell had 1.9 times the chance of older adults who did not fall to complain of muscle weakness, although this factor was not maintained as a predictor of falls in multivariate analysis. Previous studies have shown inconsistent results in relation to indicating muscle weakness as a risk factor for falls among cognitively impaired older adults ${ }^{8,10,34}$. It is also possible that the complaint of muscle weakness investigated in the present study reveals other physical-functional and personal aspects that go beyond the components of muscle mass and strength.

Older adult fallers complained 22.5\% more about body imbalance than non-fallers and had 2.7 times the chance of non-fallers to describe the perception of this condition during intake. Additionally, the complaint of body imbalance correctly identified 
$80.9 \%$ of fallers, signaling the importance of continuing this line of investigation in order to improve the early identification of the risk of falling among older adults with cognitive impairment using this question. In previous studies, the decline in body balance in older adults with cognitive impairment was identified by means of stabilometric posturography variables $^{12,35}$, and these deficiencies in body balance were shown to be associated with an increased risk of falls in older adults with cognitive impairment and dementia ${ }^{6,8,34}$. However, despite these significant associations, simple balance assessment tests, such as Romberg and the Timed Get Up and Go, revealed lower estimates of accuracy for recognizing the risk of falls in older adults with cognitive impairment than those identified in the present study through the complaint of body imbalance ${ }^{36}$.

Excess worry and anxiety about walking was more frequent among older adults who fell, but not enough to maintain the complaint of insecurity when walking as a predictor of falls in the older adults in the study. Despite the high frequency of insecurity when walking observed in the groups, older adults did not present significant mobility limitations when assessed by SAM-Br. Previous findings indicate that it is precisely changes in gait and mobility that are associated with an increased risk of falling in older adults with cognitive impairment and dementia ${ }^{7,11,31,34}$. However, these changes in gait can be subtle in the early stages of dementia, and do not justify the increased occurrence of falls alone ${ }^{1}$.

The present study investigated several possible risk factors for falls among older adults with cognitive deficits, using mostly simple questions about the perception of signs and/or symptoms, in addition

\section{REFERENCES}

1. Taylor ME, Delbaere K, Close JCT, Lord SR. Managing falls in older patients with cognitive impairment. Aging Health [Internet]. 2012 [acesso em 29 ago. 2018];8(6):573-88. Disponível em: https:// www.futuremedicine.com/doi/10.2217/ahe.12.68 to rapid application tools validated for this older profile. The analyzes were performed in a sample size suggested by a priori calculation. The reporting of previous falls was restricted to the previous six months in order to reduce recall bias. However, despite these strengths, the heterogeneity of the severity of cognitive deficits and the different pathophysiological mechanisms included may have influenced the findings. In addition, the crosssectional design of the study does not allow a causal relationship of the investigated risk factors and the occurrence of falls to be established.-

\section{CONCLUSION}

According to the results of this study, a high frequency of falls was identified among cognitively impaired older adults and it was found that polypharmacy and the perception of visual impairment and body imbalance by older adults or their caregivers are factors associated with falls, although with poor accuracy. These findings inform care teams of cognitively impaired older adults that the inclusion of these simple, quick questions in the clinical routine and in research can contribute to screening the risk of falling in this population and favor early intervention in modifiable factors.

\section{ACKNOWLEDGEMENTS}

The author would like to thank the geriatrician Luciana Lillian Louzada Martini for her contributions to the conception and implementation of the study.

Edited by: Ana Carolina Lima Cavaletti
2. Hugo J, Ganguli M. Dementia and cognitive impairment. Epidemiology, Diagnosis, and Treatment. Clin Geriatr Med [Internet]. 2014 [acesso em 13 abr. 2020];30(3):421-42. Disponível em: https://www.geriatric.theclinics.com/article/S07490690(14)00036-6/fulltext 
3. Rolenz E, Reneker JC. Validity of the 8-Foot Up and Go, Timed Up and Go, and Activities-Specific Balance Confidence Scale in older adults with and without cognitive impairment. J Rehabil Res Dev [Internet]. 2016 [acesso em 29 ago. 2018];53(4):511-8. Disponível em: http://www.rehab.research.va.gov/ jour/2016/534/pdf/JRRD-2015-03-0042.pdf

4. Whitney J, Jackson SHD, Close JCT, Lord SR. Development and validation of a fall-related impulsive behaviour scale for residential care. Age Ageing [Internet]. 2013 [acesso em 29 ago. 2018];42(6):754-8. Disponível em: https://academic.oup.com/ageing/ article-lookup/doi/10.1093/ageing/aft130

5. Borges SDM, Radanovic M, Forlenza OV. Fear of falling and falls in older adults with mild cognitive impairment and Alzheimers disease. Aging Neuropsychol Cogn [Internet]. 2015 [acesso em 29 ago. 2018];22(3):312-21. Disponível em: https:// www.tandfonline.com/doi/abs/10.1080/13825585.2 014.933770

6. Fernando E, Fraser M, Hendriksen J, Kim CH, Muir-Hunter SW. Risk factors associated with falls in older adults with dementia: a systematic review. Physiother Can [Internet]. 2017 [acesso em 07 out . 2018];69(2):161-70. Disponível em: http://www.ncbi. nlm.nih.gov/pubmed/28539696

7. Pellfolk T, Gustafsson T, Gustafson Y, Karlsson S. Risk factors for falls among residents with dementia living in group dwellings. Int Psychogeriatr [Internet]. 2009 [acesso em 29 ago. 2018];21(1):187-94. Disponível em: http://www.journals.cambridge.org/ abstract_S1041610208007837

8. Taylor ME, Lord SR, Delbaere K, Mikolaizak AS, Close JCT. Physiological fall risk factors in cognitively impairedo older people: a one-year prospective study. Dement Geriatr Cogn Disord [Internet]. 2012 [acesso em 04 abr. 2019];34(3-4):181-9. Disponível em: http:// www.ncbi.nlm.nih.gov/pubmed/23076047

9. Uemura K, Shimada H, Makizako H, Doi T, Tsutsumimoto K, Yoshida D, et al. Effects of mild and global cognitive impairment on the prevalence of fear of falling in community-dwelling older adults. Maturitas [Internet]. 2014 [acesso em 02 out.2018];78(1):62-6. Disponível em: https://www. maturitas.org/article/S0378-5122(14)00071-1/fulltext

10. Taylor ME, Ketels MM, Delbaere K, Lord SR, Mikolaizak AS, Close JCT. Gait impairment and falls in cognitively impaired older adults: an explanatory model of sensorimotor and neuropsychological mediators. Age Ageing [Internet]. 2012 [acesso em 05 out. 2018];41(5):665-9. Disponível em: https://academic.oup.com/ageing/article-lookup/ doi/10.1093/ageing/afs057
11. Muir SW, Speechley M, Wells J, Borrie M, Gopaul K, Montero-Odasso M. Gait assessment in mild cognitive impairment and Alzheimer's disease: the effect of dual-task challenges across the cognitive spectrum. Gait Posture [Internet]. 2012 [acesso em 05 out. 2018];35(1):96-100.Disponível em: http://www. ncbi.nlm.nih.gov/pubmed/21940172

12. Shin BM, Han SJ, Jung JH, Kim JE, Fregni F. Effect of mild cognitive impairment on balance. J Neurol Sci [Internet]. 2011 [acesso em 02 out. 2018];305(1-2):1215. Disponível em: https://www.jns-journal.com/ article/S0022-510X(11)00107-9/fulltext

13. Alves RLT, Silva CFM, Pimentel LN, Costa IA, Souza ACS, Coelho LAF. Evaluation of risk factors that contribute to falls among the elderly. Rev Bras Geriatr Gerontol [Internet]. 2017 [acesso em 12 abr. 2018];20(1):56-66. Disponível em: http://www.scielo.br/scielo.php?script=sci_ arttext\&pid=S1809-98232017000100056

14. Herrera E, Caramelli P, Silveira ASB, Nitrini R. Epidemiologic survey of dementia in a communitydwelling brazilian population. Alzheimer Dis Assoc Disord [Internet]. 2002 [acesso em 04 abr. 2019];16(2):103-8. Disponível em: http://www.ncbi. nlm.nih.gov/pubmed/12040305

15. Cruz DT, Leite ICG. Falls and associated factors among elderly persons residing in the community. Rev Bras Geriatr Gerontol [Internet]. 2018 [acesso em 03 set. 2019];21(5):532-41. Disponível em: http://www. scielo.br/scielo.php?script=sci_arttext\&pid=S180998232018000500532\&lng=en\&tlng=em

16. Tieges Z, Evans JJ, Neufeld KJ, MacLullich AMJ. The neuropsychology of delirium: advancing the science of delirium assessment. Int J Geriatr Psychiatry [Internet]. 2018 [acesso em 22 mar. 2019];33(11):1501-11. Disponível em: https://www. ncbi.nlm.nih.gov/pubmed/28393426

17. Wang CW, Chan CLW, Chi I. Overview of quality of life research in older people with visual impairment. Adv Aging Res [Internet]. 2014 [acesso em 03 set 2019];3(2):79-94. Disponível em: http:// www.scirp.org/journal/doi.aspx?DOI=10.4236/ aar.2014.32014

18. Egerton T, Chastin SFM, Stensvold D, Helbostad JL. Fatigue may contribute to reduced physical activity among older people: an observational study. J Gerontol Ser A Biol Sci Med Sci [Internet]. 2016 [acesso em 03 set. 2019];71(5):6706. Disponível em: http://www.ncbi.nlm.nih.gov/ pubmed/26347508 
19. Richardson K, Bennett K, Kenny RA. Polypharmacy including falls risk-increasing medications and subsequent falls in community-dwelling middleaged and older adults. Age Ageing [Internet]. 2015 [acesso em 28 fev. 2019];44(1):90-6. Disponível em: https://academic.oup.com/ageing/article-lookup/ doi/10.1093/ageing/afu141

20. Ávila-Funes JA, Amieva H, Barberger-Gateau P, Le Goff M, Raoux N, Ritchie K, et al. Cognitive impairment improves the predictive validity of the phenotype of frailty for adverse health outcomes: the three-city study. J Am Geriatr Soc. 2009;57(3):453-61.

21. Tuunainen E, Rasku J, Jäntti P, Pyykkö I. Risk factors of falls in community dwelling active elderly. Auris Nasus Larynx [Internet]. 2014 [acesso em 03 set. 2019];41(1):10-6. Disponível em: https://linkinghub. elsevier.com/retrieve/pii/S0385814613001211

22. Mignardot J-B, Deschamps T, Goff CG Le, Roumier F-X, Duclay J, Martin A, et al. Neuromuscular electrical stimulation leads to physiological gains enhancing postural balance in the pre-frail elderly. Physiol Rep [Internet]. 2015 [acesso em 03 set. 2019];3(7):e12471 [9 p.]. Disponível em: https://www. ncbi.nlm.nih.gov/pmc/articles/PMC4552546/

23. Malini F, Lopes C, Lourenço R. Medo de quedas em idosos: uma revisão da literatura. Rev HUPE [Internet]. 2014 [acesso em 03 set 2019];13(2):38-44. Disponível em: http://www.e-publicacoes.uerj.br/ index.php/revistahupe/article/view/10127

24. Velazquez-Alva MC, Irigoyen Camacho ME, Lazarevich I, Delgadillo Velazquez J, Acosta Dominguez P, Zepeda Zepeda MA. Comparison of the prevalence of sarcopenia using skeletal muscle mass index and calf circumference applying the European consensus definition in elderly Mexican women. Geriatr Gerontol Int [Internet]. 2017 [acesso em 03 set. 2019];17(1):161-70. Disponível em: https:// onlinelibrary.wiley.com/doi/abs/10.1111/ggi.12652

25. Alencar MA, Dias JMD, Figueiredo LC, Dias RC. Força de preensão palmar em idosos com demência: estudo da confiabilidade. Braz J Phys Ther [Internet]. 2012 [acesso em 29 ago. 2018];16(6):510-14.Disponível em: http://www.scielo.br/pdf/rbfis/v16n6/ aop057_12_sci1362.pdf

26. Lenardt MH, Binotto MA, Carneiro NHK, Cechinel C, Betiolli SE, Lourenço TM, et al. Handgrip strength and physical activity in frail elderly. Rev Esc Enferm USP [Internet]. 2016 [acesso em 03 set. 2019];50(1):86-92. Disponível em: http://www. scielo.br/scielo.php?script $=$ sci_arttext\&pid $=$ S008062342016000100086\&lng=en\&tlng=em
27. Pereira LSM, Marra TA, Faria CDCM, Pereira DS, Martins MAA, Dias JMD, et al. Adaptação transcultural e análise da confiabilidade do Southampton Assessment of Mobility para avaliar a mobilidade de idosos brasileiros com demência. Cad Saúde Pública [Internet]. 2006 [acesso em 23 set. 2018];22(10):2085-95. Disponível em: http://www. scielo.br/scielo.php?script $=$ sci_arttext\&pid=S0102311X2006001000014\&lng=pt\&tlng=pt

28. Assis LO, Assis MG, De Paula JJ, Malloy-Diniz LF. O questionário de atividades funcionais de pfeffer: revisão integrativa da literatura brasileira. Estud Interdiscip Envelhec [Internet]. 2015 [acesso em 23 set. 2018];20(1):297-324.Disponível em: https:// www.researchgate.net/publication/281443128_O_ Questionario_de_Atividades_Funcionais_de_ Pfeffer_revisao_integrativa_da_literatura_brasileira

29. Gorman E, Hanson HM, Yang PH, Khan KM, Liu-Ambrose T, Ashe MC. Accelerometry analysis of physical activity and sedentary behavior in older adults: a systematic review and data analysis. Eur Rev Aging Phys Act [Internet]. 2014 [acesso em 3 set 2019];11(1):35-49. Disponível em: http://link.springer. com/10.1007/s11556-013-0132-x

30. Cardozo NR, Druva PA, Cascaes AM, Silva AE, Orlandi SP. Estado nutricional de idosos atendidos por unidades de saúde da família na cidade de PelotasRS. BRASPEN J [Internet]. 2017 [acesso em 03 set. 2019];32(1):94-8. Disponível em: http://www.braspen. com.br/home/wp-content/uploads/2017/04/16-AOEstado-nutricional-de-idosos.pdf

31. Eriksson S, Gustafson Y, Lundin-Olsson L. Risk factors for falls in people with and without a diagnose of dementia living in residential care facilities: a prospective study. Arch Gerontol Geriatr [Internet]. 2008 [acesso em 07 out 2018];46(3):293-306.

Disponível em: https://www.sciencedirect.com/ science/article/pii/S0167494307001276?via\%3Dihub

32. Lee CY, Chen LK, Lo YK, Liang CK, Chou MY, Lo $\mathrm{CC}$, et al. Urinary incontinence: an under-recognized risk factor for falls among elderly dementia patients. Neurourol Urodyn [Internet]. 2011 [acesso em 27 fev. 2019];30(7):1286-90. Disponível em: https:// onlinelibrary.wiley.com/doi/abs/10.1002/nau.21044

33. Barnes DE, Alexopoulos GS, Lopez OL, Williamson JD, Yaffe K. Depressive symptoms, vascular disease, and mild cognitive impairment. Arch Gen Psychiatry [Internet]. 2006 [acesso em 27 fev. 2019];63(3):273-9. Disponível em: http://archpsyc.jamanetwork.com/ article.aspx?doi=10.1001/archpsyc.63.3.273 
34. Whitney J, Close JCT, Jackson SHD, Lord SR. Understanding risk of falls in people with cognitive impairment living in residential care. J Am Med Dir Assoc [Internet]. 2012 [ acesso em 04 set. 2018];13(6):535-40. Disponível em: https://wwwsciencedirect.ez54.periodicos.capes.gov.br/science/ article/pii/S1525861012000904?via\%3Dihub

35. Borges APO, Carneiro JAO, Zaia JE, Carneiro AAO, Takayanagui OM. Evaluation of postural balance in mild cognitive impairment through a three-dimensional electromagnetic system. Braz J
Otorhinolaryngol [Internet]. 2016 [acesso em 02 out. 2018];82(4):433-41. Disponível em: https:// www.sciencedirect.com/science/article/pii/ S1808869415002396

36. McMichael KA, Vander Bilt J, Lavery L, Rodriguez E, Ganguli M. Simple Balance and Mobility Tests Can Assess Falls Risk When Cognition Is Impaired. Geriatr Nurs (Minneap) [Internet]. 2008 [acesso em 04 abr.2018];29(5):311-23. Disponível em: S0197457207003230?via\%3Dihub 